Francis Jones, Daniel Annan and Saef Shah Office for National Statistics

\title{
The distribution of household income 1977 to 2006/07
}

two he 30 years between 1977 and 2007 can be subdivided almost exactly into two halves: a period of substantial change to the income distribution (1977 to 1991), and a period of relative stability (1992 to 2007). Those changes which did take place in the latter of these two periods should be understood in the context of the more substantial changes which took place in the earlier period. The changes which took place between 1977 and 1991 are of continued relevance, since the current income distribution is, to a large extent, the product of those years.

During the 1980s there was a substantial increase in income inequality caused by increased inequality in the distribution of income from wages and salaries. Between 1977 and 1991 the share of total disposable income received by the top fifth of households (or quintile group) increased from 36 to 42 per cent. The shares received by each of the lower three quintile groups fell, in the case of the bottom quintile group from 10 to 7 per cent.

In comparison, the changes which took place between 1992 and 2006/07 were much smaller, with relatively little overall change in the income shares of each quintile group over this period. Income inequality narrowed slightly in the early 1990s, widening again in the late 1990s. It narrowed again between 2001/02 and $2004 / 05$, only to widen once more between 2004/05 and 2006/07.

Between 1977 and 1996/97 the proportion of retired households in the bottom income quintile group decreased, while the proportion of children living in households in the bottom quintile group increased. From 1996/97 to 2006/07 the proportion of retired households in the bottom quintile group remained largely unchanged, and there was some decline in the proportion of children in the bottom quintile group.

There was a large increase in income inequality among both retired and nonretired households during the 1980s. Between 1990 and 2006/07 there were periods of rising and falling inequality for both groups. However, whereas the level of inequality among non-retired households in $2006 / 07$, was very similar to the level in 1990, among retired households there was a small reduction in inequality over this period.

\section{The Redistribution of Income (ROI) analysis}

Most of the data presented here are drawn from the ONS's analysis 'The effects of taxes and benefits on household income', which is also known as the Redistribution of Income (ROI) analysis. The ROI is published annually in Economic \& Labour Market Review, and previously in Economic Trends. It presents an analysis of the income distribution which is focused particularly on the way in which government intervention, through taxes and benefits, redistributes income among households.

The ROI analysis uses household income and expenditure data collected through the Expenditure and Food Survey (EFS) (or the Family Expenditure Survey (FES) 
before 2001/02). It has employed a broadly consistent methodology since 1987 and, by recalculating estimates for the period between 1977 and 1986, a consistent dataset has been produced to allow analysis of changes to the distribution and redistribution of household income over the last 30 years. The estimates presented here are for calendar years up until 1992, and for financial years from 1993/94 onwards.

The income distribution in the ROI analysis is based on a ranking of households by equivalised disposable household income. Disposable income includes income from employment and selfemployment, state benefits, occupational pensions and investment income less payments of income tax, national insurance contributions and council tax. Incomes are equivalised to adjust for differences in household size and composition. The ROI uses the McClements scale (see Jones 2008). Estimates presented in the annual ROI analysis are in current prices, although here, where the main focus is on change over time, income estimates are adjusted to remove the effects of inflation using the implied deflator for Household Final Consumption Expenditure from the UK National Accounts.

\section{Households Below Average Income (HBAl)}

There is some overlap between results presented here and the Households Below Average Income (HBAI) statistics produced by the Department for Work and Pensions (DWP). Since 1994/95, HBAI has been based on the Family Resources Survey (FRS) (for years before 1994/95, it too was based on the FES). The HBAI and ROI analyses provide complementary statistics on the income distribution. The ROI concentrates on redistribution through taxes and benefits, while HBAI focuses more on individuals in low income households. Due to the larger sample size of the FRS, the HBAI measures of the income distribution tend to be regarded as definitive. Nevertheless, the ROI's detailed breakdown of taxes, benefits and other income sources provides additional insights which make it possible to explain changes to the income distribution.

In the first section of this article, which summarises changes to the income distribution, some key results from the ROI analysis are shown alongside the closest equivalent HBAI series for comparison. The intention of the comparison is to show that the main messages from the two data sources are broadly consistent, rather than to focus on what relatively small differences there might be.

The HBAI series used for comparison comprise data published by the DWP for the years from 1994/95 onwards, and data provided by the Institute for Fiscal Studies (IFS) for the years before 1994/95. The IFS data for these years are based on the FES but were calculated using a methodology similar to HBAI. The series are all BHC (before housing costs).

In addition to being based on different surveys (at least since 1994/95) there are some further methodological differences between the ROI and HBAI. One of the most important is that for the ROI the unit of analysis is the household, while for HBAI the primary unit of analysis is the person. So the income distribution appearing in HBAI is not, like in the ROI, a distribution of households, but rather a distribution of people according to the income of the household in which they live. HBAI also uses a different equivalence scale, the modified OECD scale, and for years before 2002/03 estimates are for Great Britain rather than the UK.

Both the ROI and HBAI (at least the main HBAI results) are based on repeated cross-sectional surveys rather than a panel or longitudinal survey. They show how the income distribution, and its structure, changes over time, not how the incomes of individual households change over time.

The following sections of the article describe how the distribution of household income in the UK changed over the last 30 years. They look at inequality of household income, and the way in which different sources of income contributed to changes in the income distribution. They also show where different types of households are concentrated in the income distribution, and how their positions have changed over time. The article looks separately at incomes and inequality among retired and non-retired households. All of the results presented here are based on data from the ROI analysis unless otherwise stated.

\section{The distribution of household income}

Average household disposable income, adjusted for inflation, doubled over the period between 1977 and 2006/07

(Figure 1). However, this growth in income was faster during some periods than others, and there were periods when household income fell in real terms. There was lower growth in real household income (including some years of negative growth) in both the first half of the 1980s and 1990s. This was due to the economic recessions of the early 1980s and early 1990s - in each period household income growth fell shortly after the onset of recession and remained low for four to five years. Growth was more rapid in both the late 1980s and late 1990s. With continuous growth in gross domestic product per head between 1992 and 2006/07, real household income also increased year on year from the mid-1990s onwards. However, whereas incomes grew at an average of 4 per cent per year between $1996 / 97$ and 2001/02, the rate of growth fell to 2 per cent per year between 2001/02 and 2006/07.

Income from employment (including self-employment) is the major source of household income, accounting for at least 70 per cent of pre-tax income throughout the last 30 years. It is therefore not surprising that the most important factors behind these changes in the rate of income growth were changes in the rate of earnings growth and rates of employment (Table 1). Both the late 1980s and the late 1990s saw faster growth in earnings and rising rates of

\section{Figure 1 \\ Average equivalised household income in $2006 / 07$ prices and real gross domestic product ${ }^{1}$ per head}

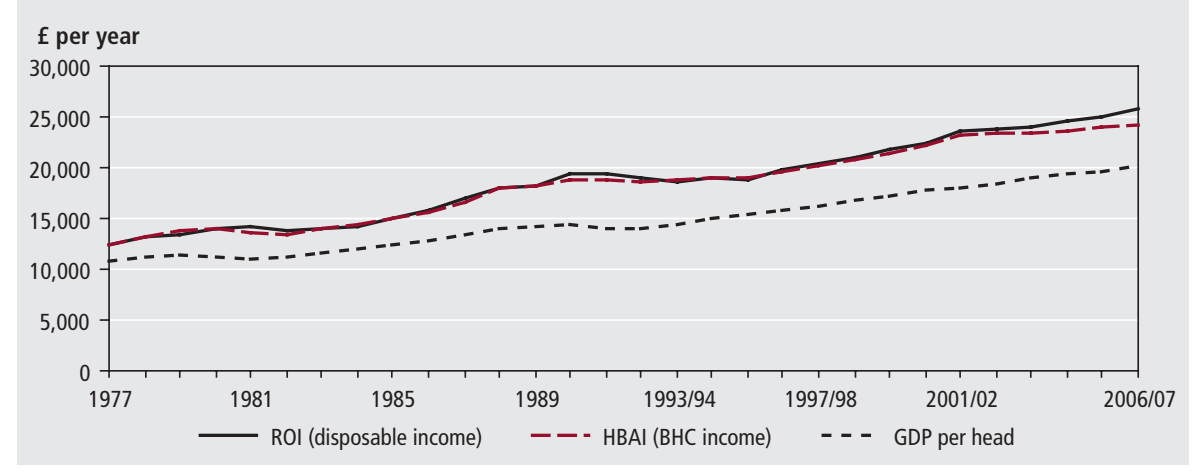

Note:

1 Chained volume measure (reference year 2003). 
Table 1

\section{Selected economic indicators}

Percentages

\begin{tabular}{|c|c|c|c|c|c|c|c|c|}
\hline & $\begin{array}{r}\text { GDP } \\
\text { growth }{ }^{1}\end{array}$ & $\begin{array}{l}\text { Average } \\
\text { earnings } \\
\text { growth }^{2}\end{array}$ & $\begin{array}{r}\text { Inflation } \\
\text { rate }^{3}\end{array}$ & $\begin{array}{r}\text { Male } \\
\text { employment } \\
\text { rate }^{4}\end{array}$ & $\begin{array}{r}\text { Female } \\
\text { employment } \\
\text { rate }^{4} \\
\end{array}$ & $\begin{array}{r}\text { Claimant } \\
\text { count rate }\end{array}$ & $\begin{array}{r}\text { Banks' } \\
\text { base } \\
\text { rates }^{6}\end{array}$ & $\begin{array}{r}\text { Growth in real } \\
\text { household } \\
\text { disposable } \\
\text { income } \\
\text { per head } \\
\end{array}$ \\
\hline 1977 & 2.4 & 9.4 & 15.8 & 88.0 & 59.0 & 4.2 & 8.9 & $\overline{-2.0}$ \\
\hline 1978 & 3.2 & 13.1 & 8.3 & 87.4 & 59.3 & 4.1 & 9.1 & 7.3 \\
\hline 1979 & 2.7 & 15.2 & 13.4 & 87.1 & 59.9 & 3.8 & 13.7 & 5.8 \\
\hline 1980 & -2.1 & 20.6 & 18.0 & 85.2 & 59.9 & 4.8 & 16.3 & 1.5 \\
\hline 1981 & -1.3 & 12.7 & 11.9 & 81.5 & 58.8 & 7.6 & 13.3 & -0.5 \\
\hline 1982 & 2.1 & 9.4 & 8.6 & 79.1 & 58.0 & 9.0 & 11.9 & -0.2 \\
\hline 1983 & 3.6 & 8.6 & 4.6 & 77.7 & 57.8 & 9.9 & 9.8 & 2.0 \\
\hline 1984 & 2.7 & 6.0 & 5.0 & 78.2 & 59.4 & 10.1 & 9.7 & 3.6 \\
\hline 1985 & 3.6 & 8.5 & 6.1 & 78.3 & 60.6 & 10.3 & 12.2 & 3.2 \\
\hline 1986 & 4.0 & 8.0 & 3.4 & 77.9 & 61.5 & 10.5 & 10.9 & 3.9 \\
\hline 1987 & 4.6 & 7.7 & 4.2 & 78.7 & 62.9 & 9.4 & 9.7 & 3.5 \\
\hline 1988 & 5.0 & 8.7 & 4.9 & 80.8 & 64.9 & 7.5 & 10.1 & 5.3 \\
\hline 1989 & 2.3 & 9.2 & 7.8 & 82.3 & 66.5 & 5.9 & 13.9 & 4.4 \\
\hline 1990 & 0.8 & 9.8 & 9.5 & 82.1 & 67.0 & 5.5 & 14.8 & 3.1 \\
\hline 1991 & -1.4 & 7.6 & 5.9 & 79.0 & 66.0 & 7.6 & 11.7 & 1.7 \\
\hline 1992 & 0.1 & 5.9 & 3.7 & 76.2 & 65.3 & 9.2 & 9.6 & 2.6 \\
\hline 1993 & 2.2 & 2.9 & 1.6 & 75.1 & 65.1 & 9.7 & 6.0 & 2.4 \\
\hline 1994 & 4.3 & 3.7 & 2.4 & 75.7 & 65.4 & 8.8 & 5.5 & 1.2 \\
\hline 1995 & 3.0 & 3.1 & 3.5 & 76.3 & 66.0 & 7.6 & 6.7 & 2.3 \\
\hline 1996 & 2.9 & 3.6 & 2.4 & 76.7 & 66.8 & 6.9 & 6.0 & 2.1 \\
\hline 1997 & 3.3 & 4.2 & 3.1 & 77.9 & 67.5 & 5.3 & 6.6 & 3.5 \\
\hline 1998 & 3.6 & 5.2 & 3.4 & 78.4 & 68.1 & 4.5 & 7.2 & 1.2 \\
\hline 1999 & 3.5 & 4.8 & 1.5 & 78.8 & 68.8 & 4.1 & 5.3 & 2.4 \\
\hline 2000 & 3.9 & 4.5 & 3.0 & 79.2 & 69.3 & 3.6 & 6.0 & 4.1 \\
\hline 2001 & 2.5 & 4.4 & 1.8 & 79.3 & 69.3 & 3.1 & 5.1 & 3.9 \\
\hline 2002 & 2.1 & 3.5 & 1.7 & 79.0 & 69.6 & 3.1 & 4.0 & 1.4 \\
\hline 2003 & 2.8 & 3.3 & 2.9 & 79.2 & 69.7 & 3.0 & 3.7 & 2.0 \\
\hline 2004 & 2.8 & 4.5 & 3.0 & 79.3 & 69.9 & 2.7 & 4.4 & 1.2 \\
\hline 2005 & 2.1 & 4.0 & 2.8 & 79.0 & 70.0 & 2.7 & 4.7 & 2.3 \\
\hline 2006 & 2.8 & 4.1 & 3.2 & 78.8 & 70.0 & 2.9 & 4.6 & 0.3 \\
\hline 2007 & 3.0 & 4.0 & 4.3 & 78.8 & 69.9 & 2.7 & 5.5 & 1.5 \\
\hline
\end{tabular}

\section{Notes:}

Source: Office for National Statistics, Bank of England

\footnotetext{
1 Annual growth in GDP at market prices (chained volume index).

2 Average earnings index; whole economy including bonuses.

3 Growth in the annual average of the retail prices index.

4 Employment rates for males aged 16 to 64 and for females aged 16 to 59.

5 Annual average of seasonally adjusted series.

6 Annual average of four UK banks' base rates; Bank of England.

7 Series IHXZ; UK National Accounts.
}

employment compared with slower growth in earnings and falling employment in the early parts of those decades. Employment rates levelled off in the early 2000s and this, combined with lower real growth in earnings, led to the slower rate of income growth in the early 2000s.

The growth in real household income between 1977 and 1991 was not equally shared across the income distribution (Figure 2). Average disposable income of the top fifth of households, or the top quintile group, increased 1.8 times in real terms between 1977 and 1991. This compares with 1.6 times for the fourth quintile group, 1.5 for the third and 1.3 for the second, while the income of the bottom quintile group increased by 1.2 times.

Over the period between 1992 and 2006/07 income growth was much more equally shared. The income of the top quintile group increased by 1.4 times in real terms, compared with 1.3 times for the fourth quintile group, and 1.4 times for each of the lower three quintile groups. It should be stressed that these figures are measures of how the income distribution changed over this period, rather than how the incomes of any particular households might have changed. Individual households, for example, may have moved between quintile groups.
The top quintile group was the most affected by cyclical variations in the rate of income growth. The second and third quintile groups were also affected, although less than the top quintile group. The bottom two quintile groups appear to have been relatively unaffected. Households in higher quintile groups contain a much higher proportion of economically active adults compared with those in lower quintile groups. Changes in employment and earnings therefore have a much greater impact on the higher quintile groups.

On the other hand, the bottom two quintile groups contain substantially more households for whom the primary source 


\section{Figure 2 \\ Equivalised household income by quintile group in 2006/07 prices}

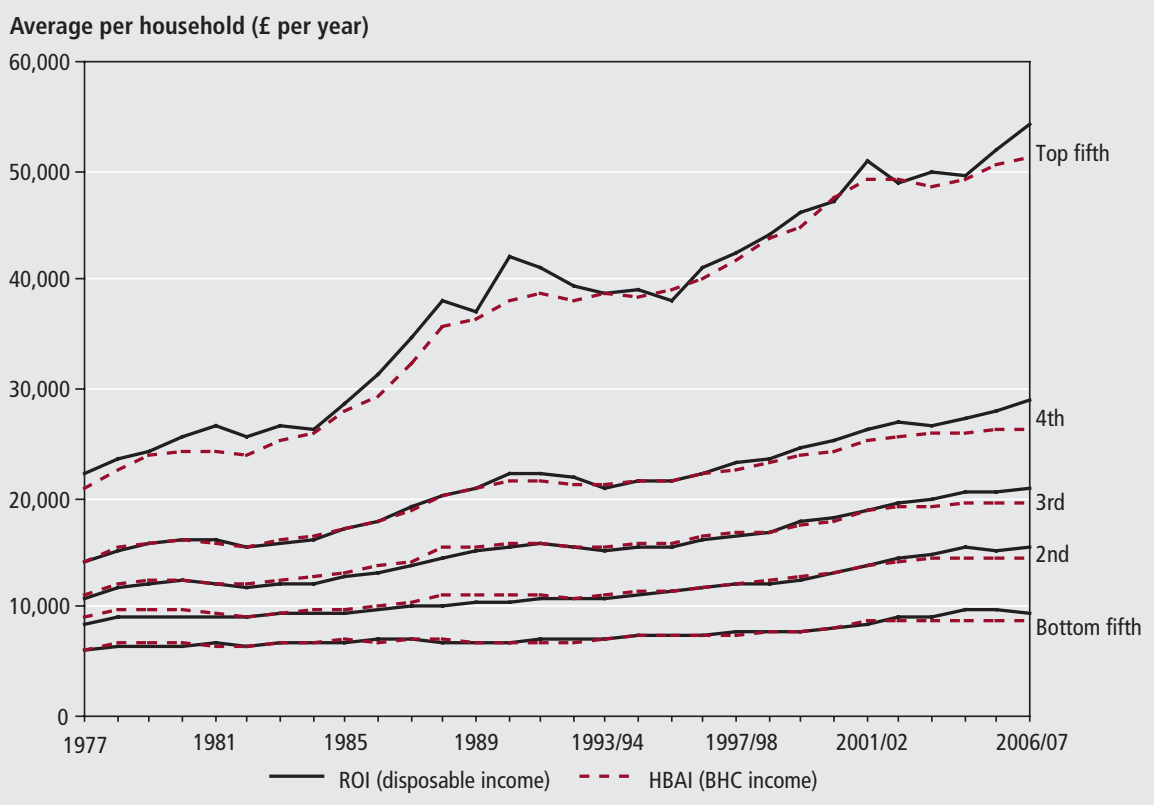

of income is state benefits, both retired households and other economically inactive households. These households would be unaffected by any downturn in earnings or employment. Even in low income households where adults are in work, they are likely to be in lower paid jobs where the differential between employment income and benefit income is lower.

Income growth for the bottom two quintile groups was slow for much of the 1980s and 1990s, although there was a period of faster growth starting in the very late 1990s and continuing until 2004/05. Average disposable income for the bottom quintile group grew by 1 per cent per year in real terms between 1980 and 1999/2000. It grew by 5 per cent per year between $1999 / 2000$ and $2004 / 05$, but then fell by 1 per cent in both 2005/06 and 2006/07. Income of the second quintile group grew by 2 per cent per year between 1977 and $1998 / 99$. It grew by 4 per cent per year between 1998/99 and 2004/05, but then was effectively unchanged between 2004/05 and 2006/07.

There was a decline in the number of people living in workless households in the late 1990s which would have contributed to income growth in the lower part of the income distribution. In addition, government policies during the period between 2001/02 and 2004/05, such as the real increases to the national minimum wage, tax credits, the basic state pension, and pension credit, certainly led to real increases in income for some low income households during this period. However, between 2004/05 and 2006/07 there was little real increase in income from benefits, and no real growth in the incomes of the bottom two quintile groups.

There was little, or no, real growth in average disposable income of the top quintile group between 2001/02 and $2004 / 05$, then relatively fast growth between $2004 / 05$ and 2006/07. Incomes for people employed in the financial sector could provide part of the explanation for this. These two periods, of first low growth and then higher growth for the top quintile group, correspond quite closely to the bursting of the 'dot-com bubble' and the subsequent recovery of equity prices (see also Brewer et al 2008).
Taken together, these trends mean that between 1977 and 2006/07 only the top quintile group increased its share of total income, from 36 to 42 per cent

(Figure 3). The share of each of the other quintile groups declined, in the case of the bottom quintile group from 10 to 7 per cent. Most of the change to the income shares of the top and the lower three quintile groups took place between 1977 and 1990, and during the mid and late 1980s especially. The income share of the fourth quintile group declined slightly but steadily over the entire period.

Some cyclical variation is apparent in the shares of total income for the bottom two quintile groups. This is because the bottom two quintile groups experienced little benefit from stronger growth in average incomes in both the second half of the 1980s and the second half of the 1990s. Consequently, their shares of total income declined during these years, catching up somewhat during periods of slower income growth such as the early 1990s and 2000s. The third and fourth quintile groups did benefit from the stronger growth in incomes during these periods, but in a way which fairly closely mirrored average incomes, and therefore is not reflected in any change in their share of income.

Between 2001/02 and 2004/05 slower income growth for the higher quintile groups was combined with increased growth for the bottom two quintile groups. Consequently there was some limited narrowing of the gap between the top and bottom of the income distribution. Income growth for the top quintile group then

\section{Figure 3 \\ Shares of total equivalised household income by quintile group}

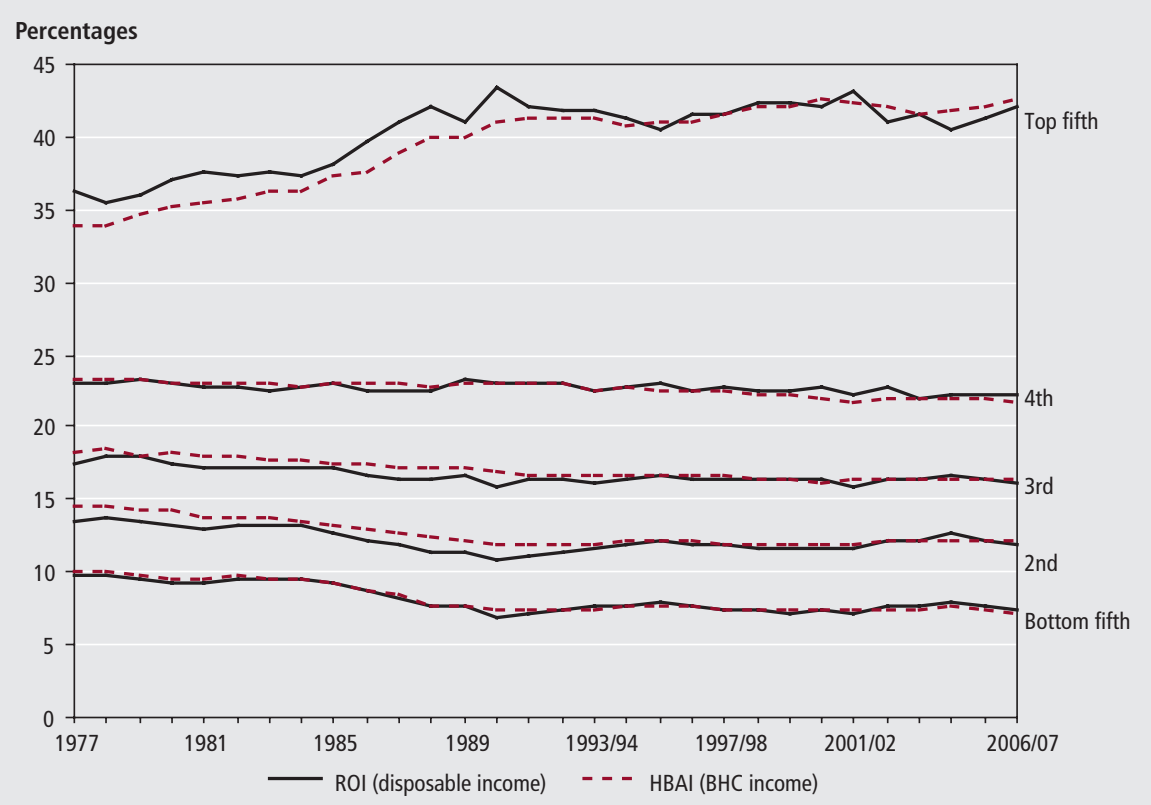


recovered between 2004/05 and 2006/07, while that for the bottom two quintile groups stalled, and any limited narrowing of the gap between 2001/02 and 2004/05 was reversed between 2004/05 and 2006/07.

While income quintile groups summarise in a useful way changes to the income distribution, it should be remembered that there can be substantial variation within these groups. This is most true of the top and bottom quintile groups. The increased share of income received by the top quintile group in fact went primarily to the highest income households within this group. The share of total income received by the top decile group increased from 22 to 27 per cent between 1977 and 2006/07

(Figure 4). The share of income received by the ninth decile group increased slightly, while that for each of the other decile groups decreased.

Research shows that the share of total income received by individuals and households in the very highest part of the income distribution, for example in the top one per cent of households, increased most rapidly of all (Atkinson and Piketty 2007, Brewer et al 2008, and Toynbee and Walker 2008). The share of total income received by these households continued to increase during the 1990s. Statistics on very high incomes are generally based on tax records rather than household surveys.

\section{Income inequality}

The extent of inequality within an income distribution is commonly measured by the Gini coefficient (see technical note 5). On the basis of this measure, inequality increased substantially between 1977 and 1990, with the most rapid increase taking place in the mid and late $1980 \mathrm{~s}$

(Figure 5). Since 1990 the Gini coefficient has fluctuated, but the level of inequality

\section{Figure 5 Gini coefficients ${ }^{1}$}

Percentages

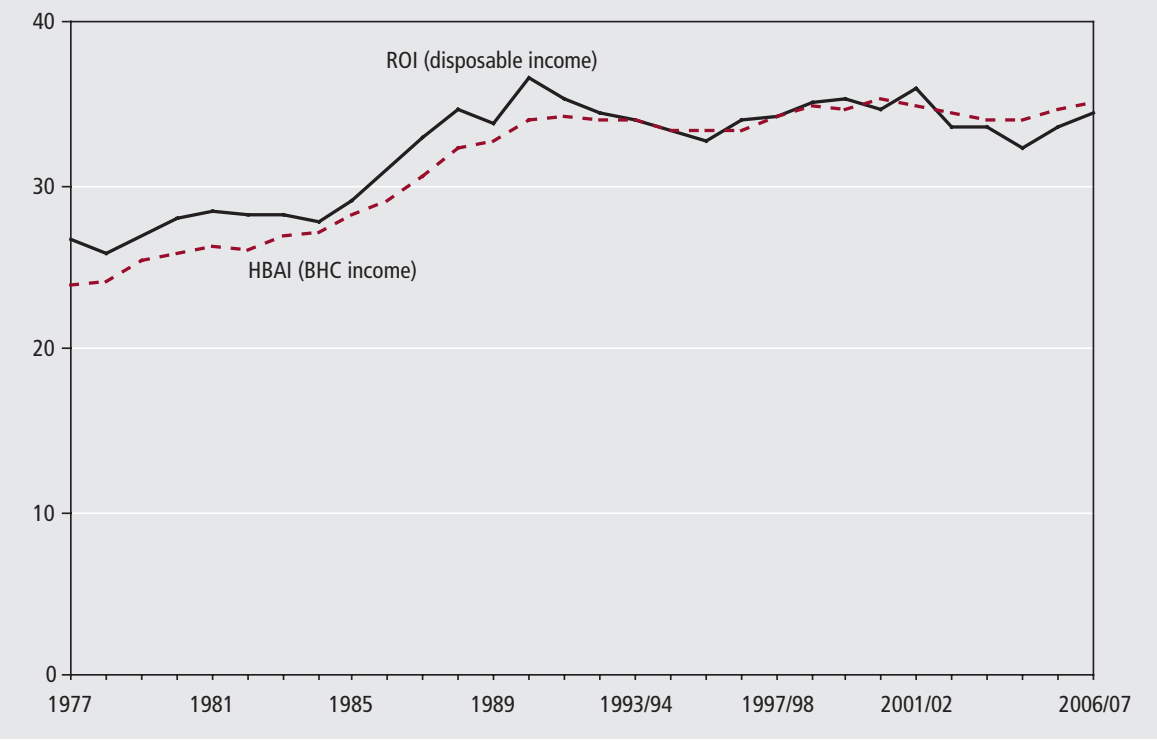

\section{Note:}

1 See technical note 5 for an explanation of the Gini coefficient.

has not returned to the levels seen in the late 1970s and early 1980s.

The Gini coefficient increased more rapidly during periods of faster growth in income from employment (the late 1980s and late 1990s) and either increased more slowly, or fell, during periods of slower growth in employment income (the early 1980s and early 1990s). As described above, the households which benefit from growth in income from employment are predominantly in the middle and upper part of the income distribution. Consequently, in periods of rapid growth in employment income, these households 'pull away', while during periods of low or falling employment income other households, those predominantly reliant on benefit and pension income, have a chance to 'catch up. The Gini coefficients also reflect the

\section{Figure 4}

\section{Shares of total equivalised disposable income by decile group, ${ }^{1}$ 1977 and 2006/07}

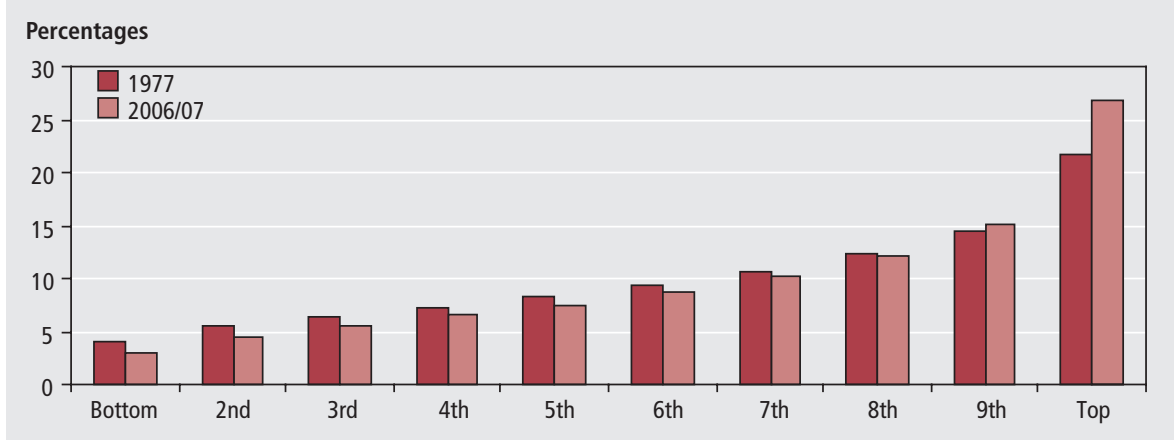

fall in income inequality between 2001/02 and 2004/05, and the subsequent increase between 2004/05 and 2006/07 described above.

While the Gini coefficient is the most commonly used measure of income inequality, alternatives can sometimes provide additional insights. The ROI analysis includes two alternative measures of inequality - the P90/P10 ratio and the $\mathrm{P} 75 / \mathrm{P} 25$ ratio. The $\mathrm{P} 90 / \mathrm{P} 10$ ratio is the ratio between the 90th and the 10th percentile in the distribution of equivalised disposable income. Over this period, the $\mathrm{P} 90 / \mathrm{P} 10$ ratio moved in a broadly similar way to the Gini coefficient (Figure 6).

The P75/P25 ratio in contrast increased much less. This is because much of the increase in inequality was due to income growth at the top of the income distribution, in other words, well above the 75th percentile. The P75/P25 ratio increased a little in the late 1980s, due to the relative decline of incomes in the lower part of the distribution. However, with the continued decline in the income share of the fourth quintile group through the 1990s and early 2000 s, the P75/P25 ratio was only slightly higher in 2006/07 than it had been in 1977 .

Income inequality is relatively high in the UK compared with many other European countries. In 2006, among the 27 member states of the European Union, the UK had the ninth (strictly the equal ninth) highest income inequality as measured by the Gini coefficient (Figure 7). Based on the 2005 data, the UK was equal fifth (there are a number of countries that have a very similar 


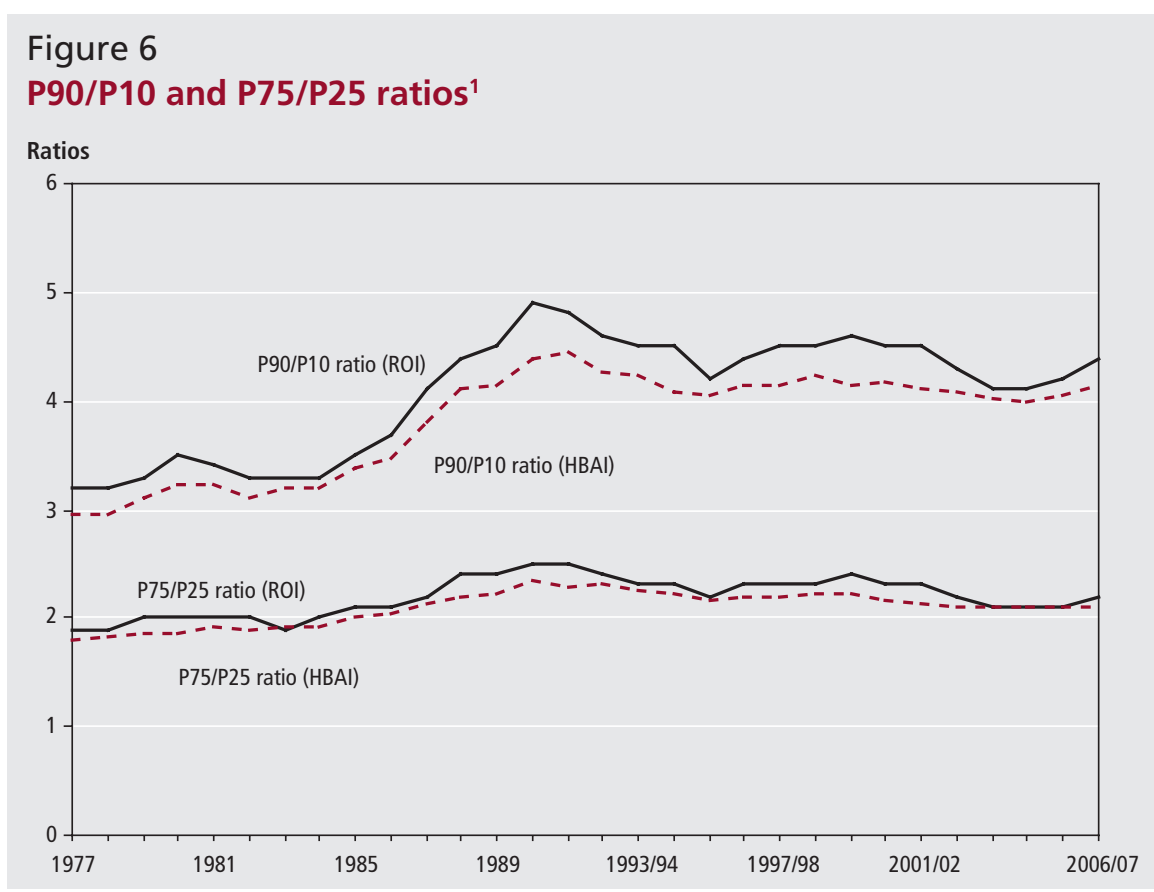

Note:

1 The HBAl estimates are those provided by the IFS for all years.

\section{Figure 7}

\section{Gini coefficients ${ }^{1}$ for European Union countries, 2006}

Percentages

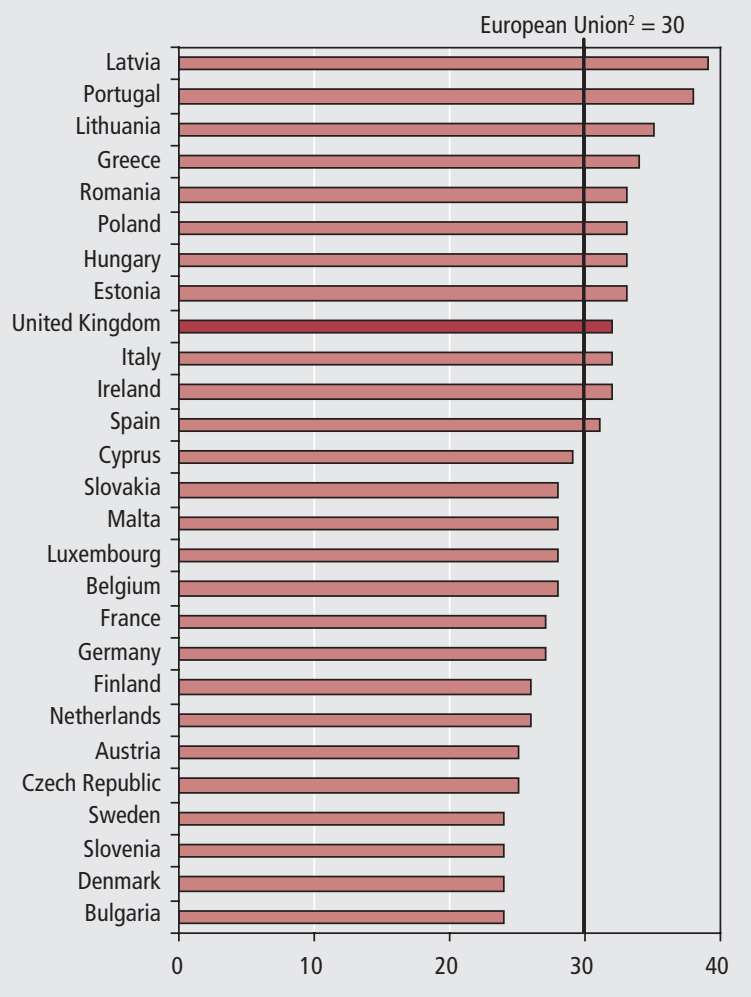

\section{Notes:}

1 See technical note 5 for an explanation of the Gini coefficient.

2 The Gini coefficient for the European Union as a whole.

level of inequality to the UK, so small changes in values can produce relatively large year to year variation in the ranking).

Income inequality in the UK is closer to that in southern European countries, such as Spain, Italy and Greece, than it is to northern European countries such as France, Germany or the Scandinavian countries. However, income inequality in the UK is lower than that in the United States. Developing countries also tend to have higher levels of inequality (World Bank 2007). The Gini coefficient is of course a single summary measure of inequality
- countries can have a similar Gini coefficient, but that does not necessarily mean that their income distributions are the same shape.

\section{Sources of household income}

Income from employment (including self-employment) is the major source of household income and over the last 30 years accounted for between 71 and 81 per cent of total gross household income (income before payment of taxes) (Figure 8).

The second largest source of income is cash benefits from government. Cash benefits include the state retirement pension, incapacity benefit, income support, housing benefit, child benefit and tax credits. Cash benefits represented a similar proportion of gross income in 2006/07 (13.2 per cent) as they did in 1977 (12.7 per cent). However, this proportion varied over time, with income from cash benefits tending to increase when income from employment fell.

Income from occupational pensions grew more rapidly than other sources of income. In 1977 occupational pensions and annuities accounted for just 2.6 per cent of gross household income, but by $2006 / 07$ this proportion had increased to 7.0 per cent.

The majority of income from employment comes from wages and salaries (Table 2). Inequality in the distribution of income from wages and salaries increased substantially between 1977 and the mid1990s. In 1977, 37 per cent of total income from wages and salaries was received by the top quintile group, compared with 3.3 per cent received by the bottom quintile group. By 1992, these proportions were 47 per cent and 1.6 per cent respectively. The share of total income from wages and salaries received by the second and third quintile groups declined, while that for the fourth quintile group remained roughly constant. This increase in inequality of income from wages and salaries between 1977 and the early 1990s was the overwhelming reason for the increase in inequality in the distribution of disposable income illustrated in Figures 2 to 5.

Between 1992 and 2006/07 this increased inequality persisted, and the share of income from wages and salaries received by the top quintile group remained around 47 or 48 per cent. However, there was a small increase in the share of income from wages and salaries received by the bottom two quintile groups at the expense of the third and fourth.

In the early 1980s self-employment 
Table 2

Income ${ }^{1}$ by quintile group and source of income for all households

\begin{tabular}{|c|c|c|c|c|c|c|c|}
\hline & \multicolumn{5}{|c|}{ Income quintile groups of all households ${ }^{2}$} & \multirow[b]{2}{*}{ All households } & \multirow{2}{*}{$\begin{array}{r}\text { Average pe } \\
\text { householc } \\
\text { (f per year } \\
2006 / 07 \text { prices }\end{array}$} \\
\hline & Bottom & 2nd & $3 r d$ & 4th & Top & & \\
\hline \multicolumn{8}{|c|}{ Income from wages and salaries ${ }^{3}$} \\
\hline 1977 & 3.3 & 10.9 & 20.7 & 28.2 & 36.9 & 100 & 13,93 \\
\hline 1981 & 2.7 & 9.2 & 19.5 & 28.3 & 40.3 & 100 & 14,93 \\
\hline 1986 & 2.0 & 6.8 & 17.9 & 29.2 & 44.2 & 100 & 14,79 \\
\hline 1992 & 1.6 & 6.0 & 16.9 & 28.6 & 46.8 & 100 & 16,14 \\
\hline 1996/97 & 1.9 & 6.5 & 16.2 & 28.1 & 47.3 & 100 & 16,78 \\
\hline $2001 / 02$ & 2.1 & 6.6 & 15.6 & 26.9 & 48.8 & 100 & 21,69 \\
\hline 2006/07 & 2.6 & 7.3 & 15.4 & 26.6 & 48.0 & 100 & 23,32 \\
\hline
\end{tabular}

Income from self-employment

1977
1981
1986
1992
$1996 / 97$
$2001 / 02$
$2006 / 07$

5.4

4.7

4.3

3.5

3.9

3.3

4.2

Occupational pensions and annuities

1977

1981

1986

1992

$1996 / 97$

2001/02

2006/07

Investment and other income

1977

1981

1986

1992

1996/97

2001/02

$2006 / 07$

Income from cash benefits

1977

1981

1986

1992

$1996 / 97$

2001/02

2006/07

less Direct taxes

1977

1981

1986

1992

1996/97

2001/02

2006/07

Total disposable income

1977

1981

1986

1992

$1996 / 97$

2001/02

2006/07
6.6

5.6

4.7

4.2

4.0

5.7

6.3

\section{3}

6.1

5.8

5.0

5.5

6.7

7.0

35.3

34.1

31.9

31.5

29.8

29.6

28.1

6.0

4.7

4.6

4.4

3.4

3.5

3.4

8.3

8.4

8.1

7.1

7.3

6.9

7.4
8.6

5.2

7.5

6.3

6.8

5.1

18.9

15.7

12.8

12.9

12.3

14.2

14.6

11.4
10.0
8.5
8.6
8.2
9.0
7.0

27.3

28.0

29.0

29.8

30.0

30.6

30.7

11.3

9.5

7.7

7.2

6.7

7.0

6.9

13.4

12.8

11.3

11.0

11.3

11.1

11.7

12.3
12.9
13.5
14.8
12.5
8.2
10.9

10.9

17.2

20.5

19.5

20.9

20.1

23.9

21.3

14.2

13.0

14.5

14.8

13.6

11.1

12.7

13.7

19.6

15.5

22.0

17.1

15.5

16.2

22.5

23.7

25.2

24.7

25.8

26.6

25.5

19.8

20.0

19.9

21.3

20.3

18.5

21.7

18.0

17.7

18.9

19.8

21.1

21.6

20.9

19.0

18.1

16.2

15.7

14.8

14.1

14.2

11.9

12.6

12.5

11.5

12.3

12.0

12.9

26.2

26.6

26.4

25.4

25.2

24.4

24.9

19.5

18.6

17.9

17.6

17.1

16.6

16.6
61.7

54.1

61.6

52.2

60.3

66.2

63.6

34.7

34.6

37.8

37.2

37.8

29.7

32.3

47.3

50.9

51.2

50.4

52.5

54.6

51.5

7.6

7.5

7.7

7.4

6.8

6.2

7.3

37.6

41.0

45.2

47.4

49.9

51.0

50.6

34.7

35.8

35.8
38.6
39.7

39.7

40.4

41.9

41.0

4,933

6147

16,785

21,691

23,325

1,373

1,518

2,010

2,253

2,604

2,605

3,036

\section{8}

694

1,025

1,395

1,671

2,071

2,431

775

1,065

1,224

1,790

1,397

1,361

1,287

2,402

3,018

3,594

3,756

3,882

4,092

4,580

4,346

4,626

4,831

4,906

5,214

6,571

7,290

\section{Notes:}

1 Unequivalised income.

2 Households are ranked by equivalised disposable income.

3 Including imputed income for company cars from 1992 onwards. 


\section{Figure 8}

\section{Gross income ${ }^{1}$ by source in $2006 / 07$ prices}

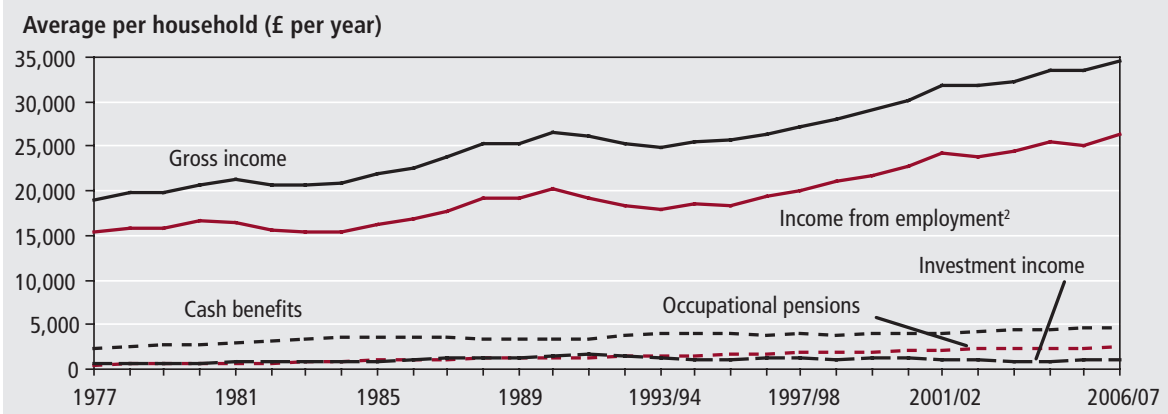

\section{Notes:}

1 Income before tax, unequivalised.

2 Including self-employment income.

income represented about 7 per cent of total gross income, increasing to around 9 per cent from the late 1980s onwards. Since self-employment income is very unequally distributed, being concentrated among higher income households, this may have made a small contribution to increasing income inequality, although selfemployment income itself did not appear to become any more unequally distributed.

The steadily increasing income from occupational pensions would have had a downward effect on inequality by increasing incomes for some retired households, thereby moving them out of the lowest income decile groups.

Cash benefits are the one major source of income received predominantly by households in lower quintile groups. Throughout this period around 60 per cent of total income from cash benefits was received by households in the bottom two quintile groups.

Direct taxes include income tax, national insurance contributions and council tax. Over the period 1977 to $2006 / 07$ there were some changes to the way in which direct taxes fell upon different parts of the income distribution. Changes in the impact of both cash benefits and direct taxes on the income distribution, and on income inequality, are discussed in more detail in the companion article 'The redistribution of household income 1977 to 2006/07'. However, in summary, compared with the effect of changing patterns of income from employment, the role played by cash benefits and direct taxes was relatively small.

The major reasons for the increase in inequality in the distribution of income from employment between 1977 and the early 1990s were discussed by Goodman and Shephard (2002). Skills-biased technological change and a decline in the role of trade unions led to an increase in the gap between wages for skilled and unskilled workers. In addition, the rate of male participation in the labour market fell, often in households where there was no other earner. Conversely there was increased female participation among those with working partners. This led to an increased polarisation between two-earner and zeroearner households.

Between the early 1990s and 2006/07 inequality of earnings continued to increase, although more slowly than during the 1980s. The Annual Survey of Hours and Earnings (ASHE), and its predecessor the New Earnings Survey, produce an earnings rather than an income distribution. The P90/P10 ratio for the distribution of weekly earnings among male employees increased from 2.3 in 1977, to 3.2 in 1992, and then to 3.7 in 2007 . Inequality of earnings also increased for women, although not by quite as much as it did for men - the corresponding figures for females were 2.4, 3.0 and 3.2 .

Since the mid-1990s there has been a fall in the proportion of people living in workless households. Between 1994 and 2001 the proportion of working age people in workless households (in Great Britain)

\section{Figure 9}

\section{Notes:}

2 Households are ranked by equivalised disposable income. fell from 14 to 12 per cent, while the proportion of children fell from 20 to 16 per cent (Labour Force Survey, ONS). These rates were largely unchanged between 2001 and 2006/07.

While it is not possible to quantify the impact of these two factors on income inequality within the constraints of the ROI analysis, the slower increase in inequality of earnings, and the reduction in worklessness, would certainly work in opposite directions. This would at least contribute to the more stable distribution of income from wages and salaries, and hence income itself, between the mid-1990s and 2006/07.

\section{The composition of the income distribution}

The largest change in the composition of the income distribution over the last 30 years has been in the position of retired households. Retired households represent about a quarter of all households - 22 per cent in 1977, increasing to about 26 per cent from the mid-1980s onwards. In 1977 retired households were largely concentrated in the lowest three income decile groups (Figure 9). However, over the subsequent 20 years, a gradual increase in income from occupational pensions for some retired households meant that by the mid-1990s there were many more retired households in higher decile groups. However, this trend stopped in the mid-1990s, and the position of retired households in the income distribution remained very similar up to $2006 / 07$.

In 1977 retired households made up 56 per cent of the bottom quintile group, but by 1996/97 this proportion had fallen to 39 per cent (Table 3). Over the same period there was an increase in one adult households and one adult households with children (both non-retired) in the bottom quintile group. In 1977 one adult

\section{Retired households ${ }^{1}$ by income decile group ${ }^{2}$}

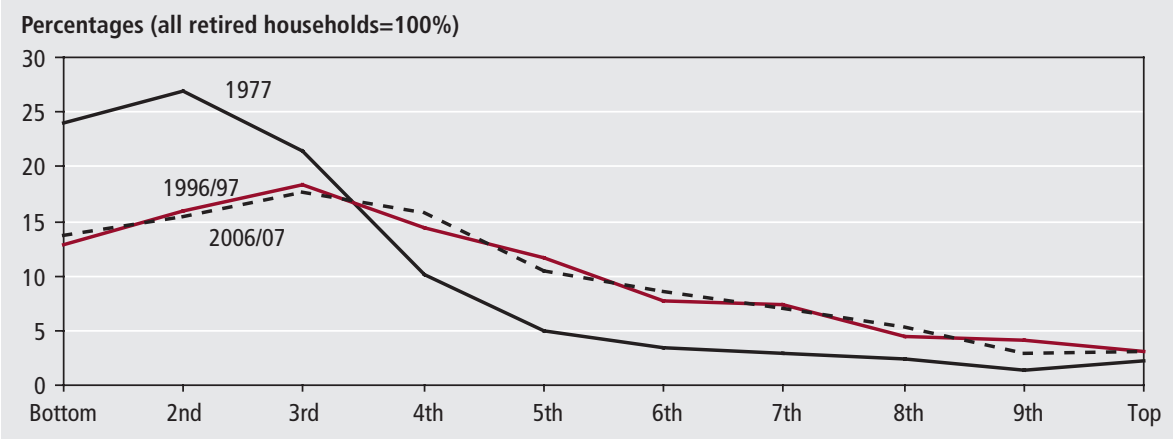

1 See technical note 4 for a definition of retired households. 
Table 3

Composition of income quintile groups by household type

Percentages

Income quintile groups of all households ${ }^{1}$

\begin{tabular}{|c|c|c|c|c|c|c|}
\hline & & \multirow[b]{2}{*}{ All households } \\
\hline & Bottom & 2nd & $3 \mathrm{rd}$ & 4th & Top & \\
\hline \multicolumn{7}{|c|}{ Retired households ${ }^{2}$} \\
\hline 1977 & 56 & 35 & 9 & 5 & 4 & 22 \\
\hline 1981 & 54 & 38 & 12 & 7 & 5 & 24 \\
\hline 1986 & 46 & 47 & 16 & 10 & 7 & 25 \\
\hline 1991 & 51 & 43 & 21 & 13 & 8 & 27 \\
\hline 1996/97 & 39 & 43 & 25 & 14 & 9 & 26 \\
\hline $2001 / 02$ & 40 & 44 & 25 & 13 & 7 & 26 \\
\hline $2006 / 07$ & 38 & 44 & 25 & 16 & 8 & 26 \\
\hline
\end{tabular}

Non-retired households

One-adult households

1977

1981

1986

1991

$1996 / 97$

2001/02

2006/07

Two-adult households

1977

1981

1986

1991

1996/97

2001/02

2006/07

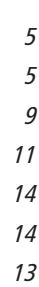

$\begin{array}{rr}5 & 7 \\ 5 & 7 \\ 7 & 10 \\ 10 & 9 \\ 10 & 12 \\ 11 & 13 \\ 10 & 15\end{array}$

$\begin{array}{rr}9 & 13 \\ 9 & 14 \\ 11 & 16 \\ 14 & 20 \\ 16 & 20 \\ 14 & 21 \\ 14 & 21\end{array}$

8
8
11
13
14
15
15

One adult with children

1977

1981

1986

1991

$1996 / 97$

2001/02

2006/07

$\begin{array}{rll}7 & 14 & 20 \\ 6 & 10 & 20 \\ 8 & 10 & 21 \\ 7 & 11 & 20 \\ 10 & 11 & 21 \\ 11 & 12 & 18 \\ 10 & 10 & 19\end{array}$

$\begin{array}{lll}28 & 43 & 22 \\ 27 & 42 & 21 \\ 27 & 40 & 21 \\ 27 & 41 & 21 \\ 26 & 39 & 21 \\ 29 & 38 & 21 \\ 28 & 38 & 21\end{array}$

Two adults with children

1977

1981

1986

1991

$1996 / 97$

$2001 / 02$

$2006 / 07$

$\begin{array}{rl}7 & 3 \\ 7 & 4 \\ 9 & 6 \\ 10 & 6 \\ 12 & 8 \\ 12 & 6 \\ 12 & 8\end{array}$

$\begin{array}{ll}2 & 1 \\ 2 & 2 \\ 3 & 1 \\ 3 & 1 \\ 3 & 1 \\ 5 & 3 \\ 4 & 3\end{array}$

Three or more adults (with or without children)

\begin{tabular}{|c|c|c|c|c|c|c|}
\hline 1977 & 5 & 11 & 23 & 24 & 20 & 17 \\
\hline 1981 & 7 & 13 & 19 & 27 & 18 & 16 \\
\hline 1986 & 6 & 9 & 17 & 23 & 17 & 14 \\
\hline 1991 & 6 & 10 & 16 & 19 & 11 & 12 \\
\hline $1996 / 97$ & 6 & 9 & 15 & 19 & 12 & 12 \\
\hline $2001 / 02$ & 9 & 9 & 15 & 18 & 13 & 13 \\
\hline $2006 / 07$ & 11 & 10 & 15 & 15 & 12 & 13 \\
\hline
\end{tabular}

\section{Notes:}

1 Households are ranked by equivalised disposable income.

2 See technical note 4 for a definition of retired households. 
households made up 5 per cent of the bottom quintile group compared with 14 per cent in 1996/97. The proportion of one adult households with children increased from 7 to 12 per cent.

Between 1977 and 2006/07 the proportion of one adult non-retired households (without children) in the population nearly doubled, from 8 to 15 per cent of all households. This increase was reflected across all quintile groups. One adult households are more likely than average to be in higher income quintile groups, although the extent to which this is true has diminished. This is likely to be, at least in part, due to the increase in two earner households which, taking into account the respective equivalisation factors, would tend to lead to a relative worsening of the position of single person households in the income distribution, compared with two adult households.

There was also a substantial increase in the total number of one adult nonretired households with children. In 2006/07 they represented 6 per cent of all households compared with 3 per cent in 1977. Along with retired households, one adult households with children are the other main group of households that are highly concentrated in the lower part of the income distribution. The combination of low employment income, and the presence of children, results in low equivalised incomes. The increase in one adult households with children in the bottom quintile group was simply due to the increase in their number, rather than any change in their overall position in the income distribution.

Two adult households with children (non-retired) formed a declining proportion of households, down from 28 per cent in 1977 to 19 per cent in 2006/07, mainly due to the increasing numbers of one adult (non-retired) households with and without children, and of retired households. Two adult households with children are slightly more likely to be found in higher income quintile groups than was the case in the past, probably due to an increase in the proportion of these households which are two earner households. In particular, the presence of two adult households with children has declined in the second and third quintile group. Their place was taken primarily by retired households, and to a lesser extent single adult households.

There was an increase in the proportion of children living in households in the lowest two decile groups between 1977 and the mid- 1990s, although this was reversed to some extent between the mid-1990s and 2006/07. The proportion of children in the lowest two decile groups increased from 19 per cent in 1977 to 29 per cent in 1996/97, mainly due to the increase in single parent households (Figure 10). There were corresponding falls in the proportions of children in the fourth to the seventh decile groups.

However, between 1996/97 and 2006/07 the proportion of children in the bottom two decile groups decreased from 29 to 25 per cent while there were increases in the proportion of children in decile groups three and four and in some of the upper decile groups. Over this period there were real increases in cash benefits for households with children, for example through tax credits. The fall in the number of children living in workless households during the late 1990s would also have contributed to this improvement in the position of children in the income distribution. Comparing the overall position of children in $2006 / 07$ with that in 1977, there was a smaller proportion of children in the middle decile groups, but a higher proportion in both the upper and lower decile groups.

\section{Incomes of retired and non- retired households}

In the ROI analysis a household is defined as retired when more than 50 per cent of the household income is received by retired members of the household (an individual is defined as retired either if they describe themselves as 'retired', or they are over state pension age and either 'unoccupied' or 'sick or injured but not intending to seek work'). The incomes of retired and non-retired households differ substantially in terms of their level, distribution and composition. Since nonretired households represent three quarters of all households, many of the results for non-retired households are quite similar to those for all households as discussed in the previous sections. Therefore, this section focuses on retired households, presenting results for non-retired households mainly for comparison only.

Average disposable income of retired households is substantially lower than that of non-retired households. Since income from pensions generally does not fluctuate from year to year and is often uprated in line with inflation, incomes of retired households have grown more steadily than those of non-retired households - the cyclical variations in average household income result almost entirely from fluctuations in the incomes of non-retired households (Figure 11).

There has been an improvement in the position of retired households compared with non-retired households. Between 1977 and 1991 the income of retired households was, on average, 61 per cent of the income for non-retired households. For the period between 1992 and 2006/07 this increased to 65 per cent (Figure 12). In the late 1980s, growth in earnings was significantly above the rate of inflation (Table 1 ) and therefore pension incomes, generally uprated in line with inflation, fell behind earned incomes. In the late 1990s and early 2000s, the gap between earnings and price inflation was lower and so the incomes of retired households did not fall as far behind those of non-retired households. Increased income from occupational pensions and the earnings-related component of the state pension further helped to maintain the incomes of retired households relative to non-retired households.

The state retirement pension formed the largest source of income for retired households until the 2000s (Figure 13). In 1977, income from occupational pensions accounted for just 18 per cent of the gross income of retired households,

\section{Figure 10 Children by income decile group ${ }^{1}$}

Percentages (all children $=100 \%$ )

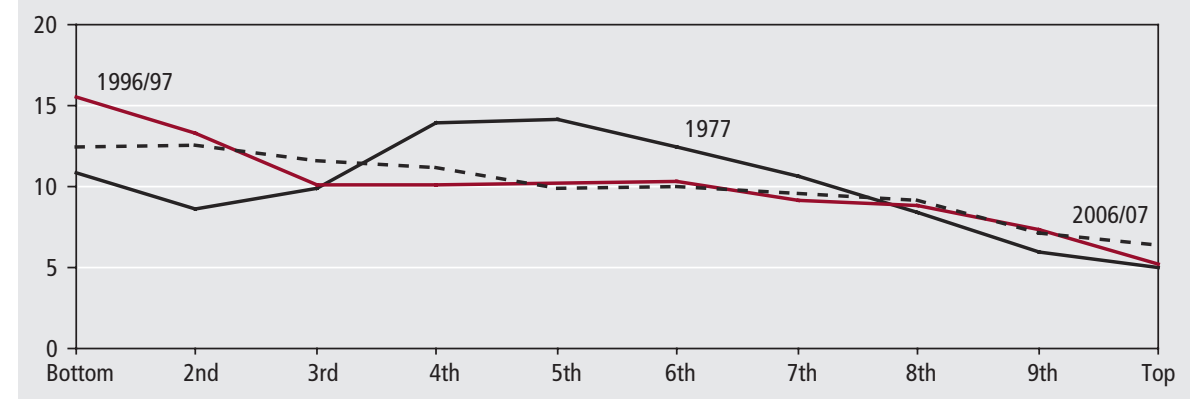

Note:

1 Households are ranked by equivalised disposable income. 


\section{Figure 11}

\section{Average equivalised disposable income for retired and non-retired households in 2006/07 prices}

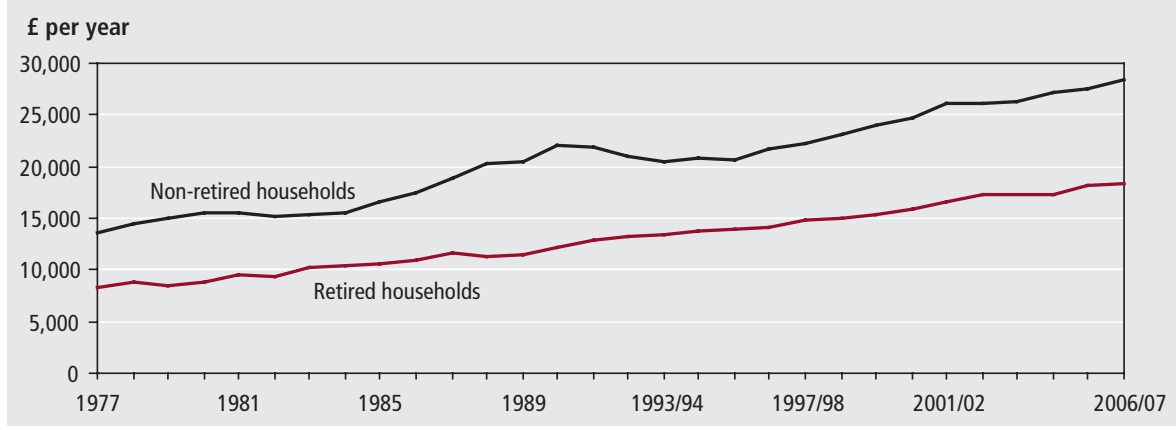

\section{Figure 12}

\section{Average equivalised income for retired households as a proportion of income for non-retired households}

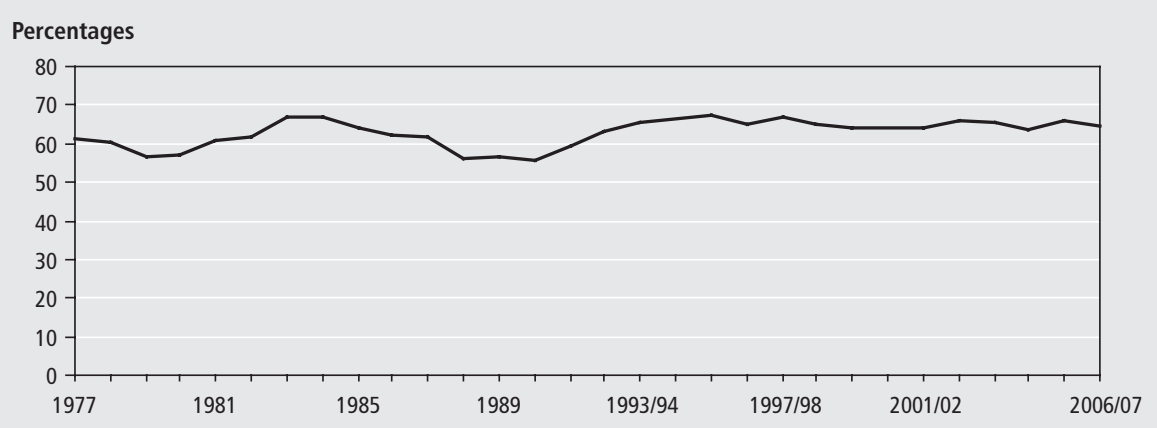

\section{Figure 13}

\section{Income ${ }^{1}$ by source for retired households in $2006 / 07$ prices}

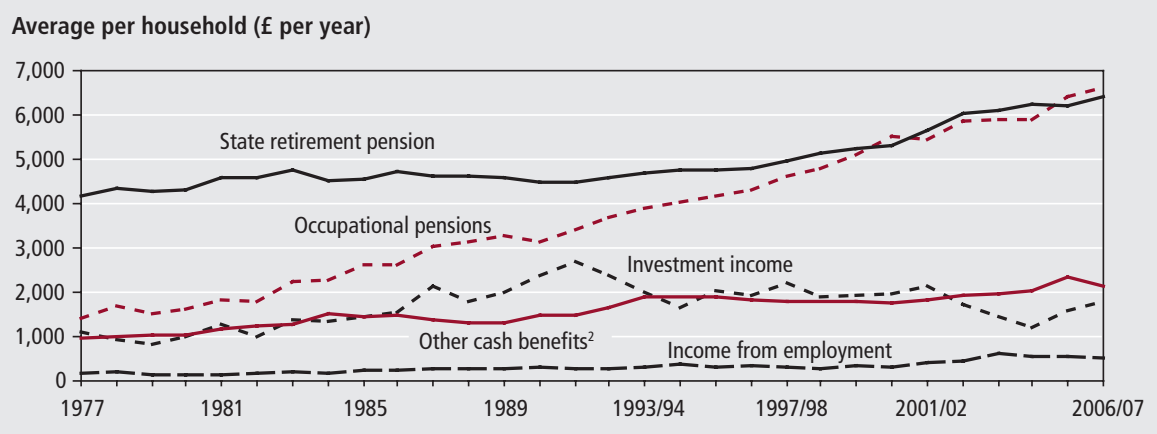

\section{Notes:}

1 Income before tax, unequivalised.

2 Includes pension credit.

compared with 53 per cent from the state retirement pension. However, income from occupational pensions increased almost continuously over the last 30 years. From around 2000 onwards occupational pensions and the state retirement pension contributed about equally to the total gross income of retired households, although incomes from these sources were distributed in very different ways among households.

There was an increase in the proportion of pensioners receiving income from occupational schemes, which was most rapid in the period from 1979 to 1996/97
(Department for Work and Pensions 2008). This was due to the major expansion of occupational pension schemes which took place during the 1950s and the 1960s. In addition, pensioners that retired in the 1990 s and early 2000s were also likely to have had longer contribution records, and higher final salaries (on which pension income may be based), than those who retired in the 1970s and 1980s.

While income from occupational pensions increased year on year, because the basic state retirement pension was uprated in line with prices, income from the state retirement pension barely increased in real terms through the 1980s and the early 1990s. Between 1996/97 and 2006/07 there was faster growth in income from the state retirement pension which was mainly due to the maturing of the earningsrelated component of the state pension (SERPS, replaced in 2002 by the state second pension) (Department for Work and Pensions 2008). Above inflation increases in the basic state pension in 2001/02 and 2002/03 also contributed to the real growth in state pension income.

Income from investments is also an important source of income for retired households. The level of investment income depends on the level of savings and financial assets of retired households, and the real rate of return on those savings and assets. After the high inflation rates of the late 1970s and early 1980s, which eroded savings, interest rates (adjusted for inflation) were at their highest around 1990 (Table 1). Since 1990, returns on investments have been somewhat lower and fell particularly during the early 2000s, recovering to some extent between 2004/05 and 2006/07.

Income from other cash benefits (that is, cash benefits other than the state retirement pension) doubled in real terms between 1977 and 1993/94. The largest increases were in housing, invalidity, disability and carer's benefits. Income from other cash benefits remained at a similar level for the remainder of the 1990s, then increased between 2000/01 and 2006/07. There were real increases in income from pension credit after its introduction in 2003/04.

In contrast to retired households, around 85 per cent of the income of non-retired households comes from employment (including self-employment). In recent years, cash benefits have accounted for around 8 per cent of the income of nonretired households, although over the last 30 years this figure has varied between 7 and 11 per cent. Since the start of the 1980s, investments and pensions have tended to account for around 4 or 5 per cent of gross income (Figure 14).

\section{Income inequality among retired and non-retired households}

The distribution of income among retired households is more equal than that among non-retired households. However, changes in the level of inequality among retired households were quite similar to those for non-retired households, even though the sources of income for these two groups are very different. 


\section{Figure 14}

\section{Income ${ }^{1}$ by source for non-retired households in 2006/07 prices}

Average per household ( $\mathrm{f}$ per year)

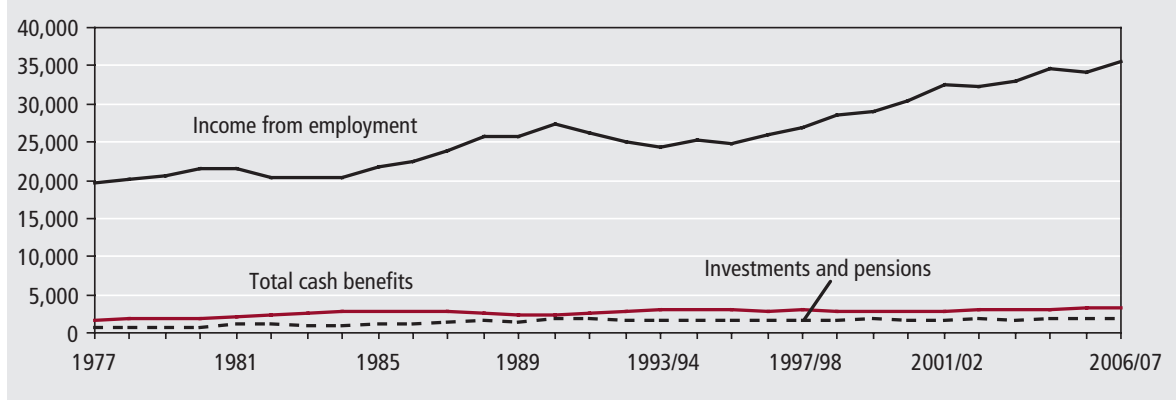

\section{Note:}

1 Income before tax, unequivalised.

Between 1977 and 1990 the top quintile group of retired households increased its share of total income (of retired households) at the expense of the lowest three quintile groups (Figure 15). Over the same period, the Gini coefficient for retired households increased by 10 points - exactly the same increase as for non-retired households (Figure 16). Among nonretired households, increased inequality was due to increased inequality of income from employment. Among retired households, it was the absence of real growth in income from the state retirement pension, combined with strong growth in income from occupational pensions and investments, which led to increased inequality.

Income from the state retirement pension is distributed relatively evenly across the quintile groups of retired households and this pattern remained stable over time (Table 4). Income from occupational pensions and investment income, on the other hand, are distributed much more unequally than income from the state pension. Between 1977 and 1991 the top quintile group generally received over 70 per cent of total income from occupational pensions and investments. It was the increase in income from occupational pensions and investment income (which are unequally distributed), relative to income from the state pension (which is equally distributed), which explains the increase in inequality among retired households between 1977 and 1991.

Between 1991 and 2006/07 the trends in the Gini coefficients for retired and nonretired households continued to follow a similar path. Changes in the level of investment income had a major influence on the share of total income of the top quintile group of retired households, and therefore on income inequality. The falls in income inequality among retired households in both the early 1990s, and again from $2001 / 02$ to $2004 / 05$, were in part due to lower levels of investment income. This latter fall was to some extent reversed between 2004/05 and 2006/07 as investment income increased again.

Taking the period between 1990 and $2006 / 07$ as a whole, the share of total disposable income of the top quintile group of retired households fell from 41 to 37 per cent, while those for the third and fourth quintile groups increased from 16 to 17 per cent and from 20 to 22 per cent respectively. The Gini coefficient for retired households also fell over this period, although it still remained much higher than in the late 1970 s and early 1980 s.

In addition to the effect of investment

\section{Figure 15}

Note:

1 Households are ranked by equivalised disposable income. income, other factors contributed to this small reduction in inequality. While income from occupational pensions continued to increase in real terms through the 1990s and early 2000s, there was increasing real growth in income from the state retirement pension, mainly due to the maturing of the earningsrelated component of the state pension.

In addition, there was a gradual increase in income from occupational pensions for households other than those in the top quintile group. The increasing number of retired households with income from occupational pensions, and the increasing size of those pension incomes, meant that from about 1990 onwards occupational pensions became an important source of income for a greater number of households in lower quintile groups, particularly the third and fourth quintile groups.

Whereas there was some fall in inequality among retired households between 1990 and 2006/07, inequality among non-retired households in 2006/07 was at the same level as at the start of the 1990s.

\section{Datasets}

The data appearing in figures and tables in this article, and also the underlying datasets upon which the analysis is based, are available for download from: www.statistics.gov.uk/StatBase/Product. asp?vlnk=10336

\section{Shares of total equivalised disposable income by quintile group ${ }^{1}$ for retired and non-retired households}

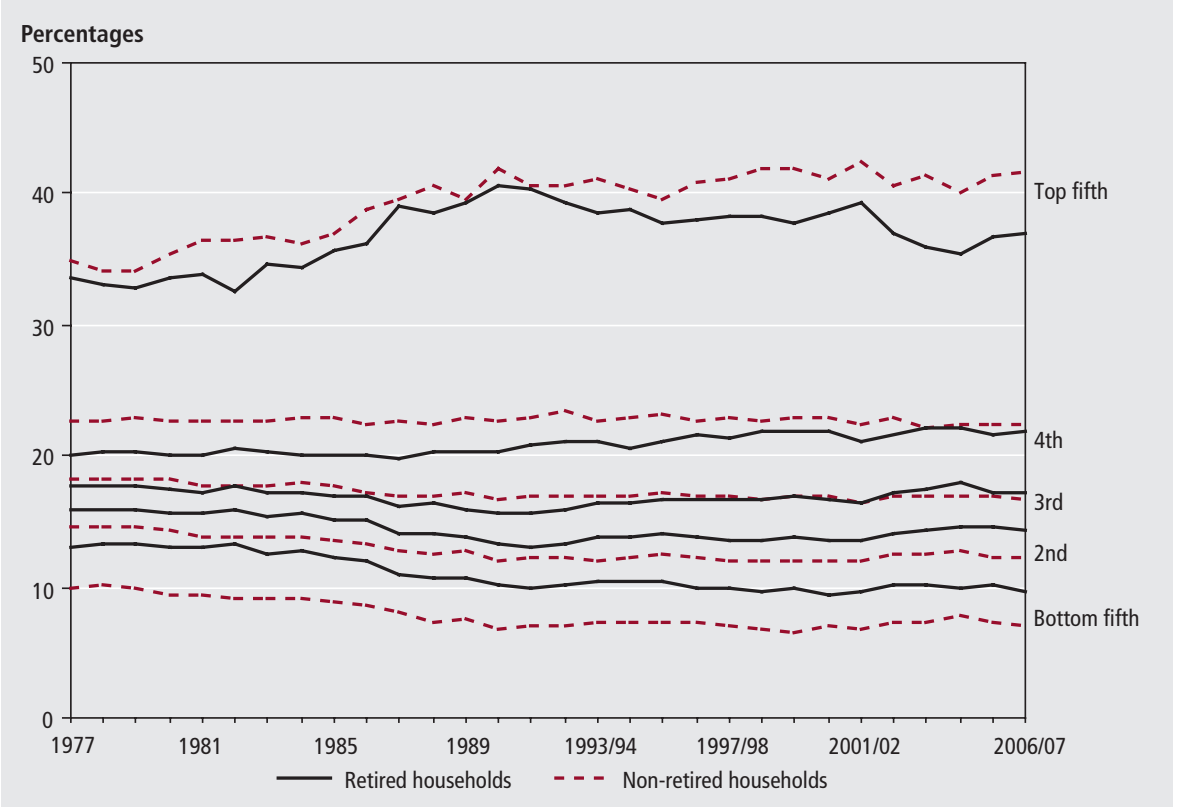


Table 4

Percentage shares of income ${ }^{1}$ by income quintile group and source of income for retired households

\begin{tabular}{|c|c|c|c|c|c|c|c|}
\hline & \multicolumn{5}{|c|}{ Income quintile groups of retired households ${ }^{2}$} & \multirow[b]{2}{*}{ All households } & $\begin{array}{l}\text { Average per } \\
\text { retired household }\end{array}$ \\
\hline & Bottom & 2nd & $3 r d$ & 4th & Top & & 2006/07 prices) \\
\hline \multicolumn{8}{|c|}{ Occupational pensions and annuities } \\
\hline 1977 & 1.9 & 3.7 & 7.3 & 16.3 & 70.7 & 100 & 1,423 \\
\hline 1981 & 1.9 & 4.0 & 7.9 & 15.5 & 70.8 & 100 & 1,836 \\
\hline 1986 & 2.2 & 4.8 & 6.4 & 17.5 & 69.1 & 100 & 2,63 \\
\hline 1991 & 2.6 & 4.3 & 3.6 & 15.0 & 74.5 & 100 & 3,408 \\
\hline $1996 / 97$ & 2.2 & 5.6 & 9.8 & 21.0 & 61.4 & 100 & 4,306 \\
\hline $2001 / 02$ & 3.3 & 7.0 & 9.7 & 23.4 & 56.6 & 100 & 5,43 \\
\hline $2006 / 07$ & 4.3 & 7.9 & 11.6 & 22.3 & 53.9 & 100 & 6,62 \\
\hline \multicolumn{8}{|c|}{ Investment income } \\
\hline 1977 & 4.2 & 4.3 & 4.6 & 8.4 & 78.4 & 100 & 1,115 \\
\hline 1981 & 4.6 & 5.2 & 5.3 & 11.5 & 73.4 & 100 & \\
\hline 1986 & 3.7 & 4.3 & 5.5 & 12.9 & 73.5 & 100 & \\
\hline 1991 & 2.9 & 2.9 & 5.6 & 14.7 & 73.8 & 100 & 2,676 \\
\hline $1996 / 97$ & 4.4 & 4.5 & 6.6 & 15.7 & 68.8 & 100 & 1,920 \\
\hline $2001 / 02$ & 3.5 & 4.4 & 7.0 & 9.9 & 75.2 & 100 & 2,150 \\
\hline $2006 / 07$ & 4.6 & 4.6 & 5.2 & 12.0 & 73.5 & 100 & 1,78 \\
\hline
\end{tabular}

Income from employment and other income

1977

$1981 \quad 6.6$

$1986 \quad 6.2$

1991

$\begin{array}{ll}1996 / 97 & 2.7\end{array}$

2001/02

$2006 / 07$

3.1

3.5

6.5

7.2

5.1

4.8

7.5

10.7

8.1

less Direct taxes

1977

1981

1986

1991

$1996 / 97$

2001/02

2006/07

Total disposable income

\begin{tabular}{|c|c|c|c|c|c|c|c|}
\hline 1977 & 12.5 & 15.7 & 16.5 & 19.6 & 35.6 & 100 & 6,731 \\
\hline 1981 & 13.1 & 15.2 & 16.2 & 19.5 & 36.0 & 100 & 7,795 \\
\hline 1986 & 11.5 & 15.0 & 15.2 & 19.9 & 38.5 & 100 & 8,923 \\
\hline 1991 & 9.5 & 12.6 & 14.6 & 21.0 & 42.3 & 100 & 10,594 \\
\hline $1996 / 97$ & 9.8 & 13.5 & 15.7 & 21.8 & 39.2 & 100 & 11,568 \\
\hline $2001 / 02$ & 9.6 & 14.0 & 15.9 & 21.1 & 39.4 & 100 & 13,513 \\
\hline $2006 / 07$ & 9.8 & 14.1 & 16.5 & 21.8 & 37.8 & 100 & 15,209 \\
\hline
\end{tabular}

\section{Notes:}

1 Unequivalised income.

2 Households are ranked by equivalised disposable income. 


\section{Figure 16 Gini coefficients ${ }^{1}$ for equivalised disposable income for retired and
non-retired households}

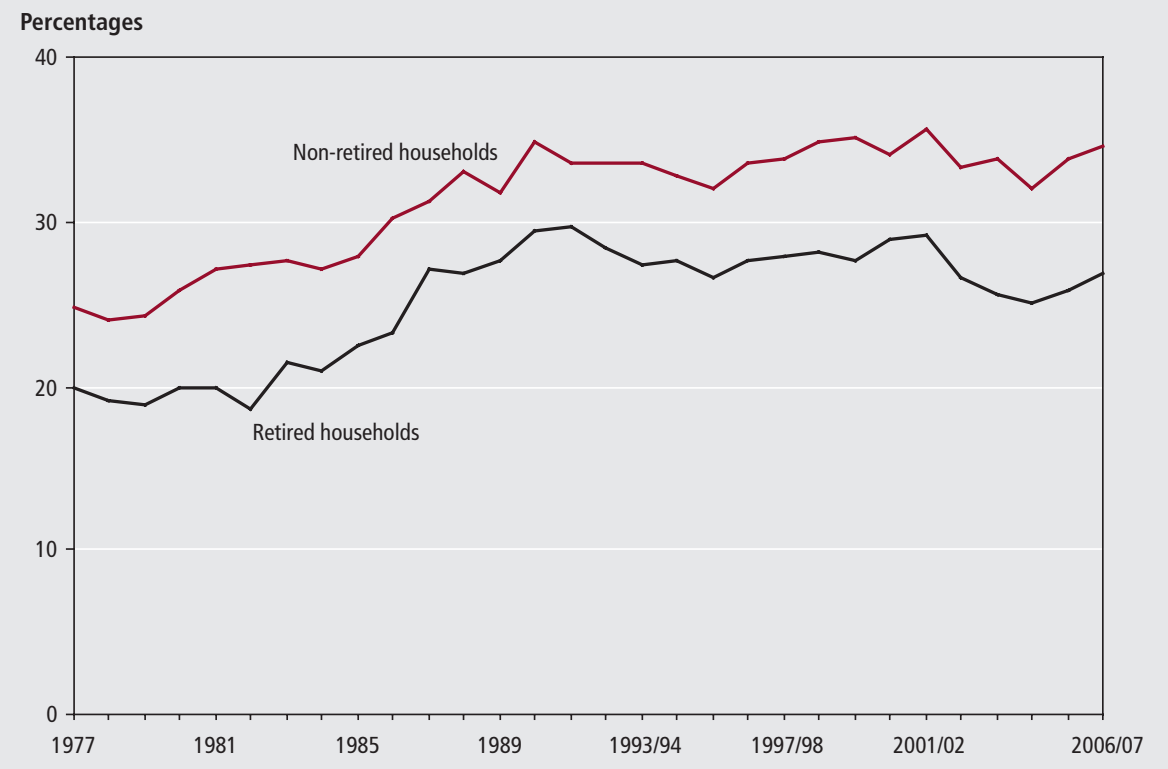

Note:

1 See technical note 5 for an explanation of the Gini coefficient.

\section{ACKNOWLEDGEMENTS}

The authors gratefully acknowledge the work done for this study by Jenny Church, Edward Franklyn, and in addition, the many people who have worked on the ROI analysis over the years, whose work has provided such a valuable source of information on the UK income distribution.

\section{REFERENCES}

Atkinson A and Piketty T (2007) 'Top Incomes over the Twentieth Century', Oxford University Press.

Brewer M, Sibieta L and Wren-Lewis L (2008) 'Racing away? Income inequality and the evolution of high incomes', The Institute for Fiscal Studies Briefing Note 76.

Department for Work and Pensions 'Households Below Average Income' at www.dwp.gov.uk/asd/hbai.asp

Department for Work and Pensions (2008) 'The Pensioners' Incomes Series 2006/07'.

Goodman A and Shephard A (2002)
'Inequality and living standards in Great Britain: some facts', The Institute for Fiscal Studies Briefing Note 19

Institute for Fiscal Studies 'Inequality and

Poverty Spreadsheet' at

www.ifs.org.uk/bns/bn19figs.zip

Institute for Fiscal Studies 'Households Below Average Income Dataset, 1961-1991' UK Data Archive.

Jones F (2008) 'The effects of taxes and benefits on household income 2006/07', Economic \& Labour Market Review 2(7), pp 37-47 and at www.statistics.gov.uk/cci/article. asp id $=2022$

Office for National Statistics 'The effects of taxes and benefits on household income' at www.statistics.gov.uk/statbase/product. asp?vlnk=10336

Toynbee P and Walker D (2008) 'Unjust Rewards: exposing greed and inequality in Britain today', Granta Books.

World Bank (2007) 'World Development Indicators 2007'.

\section{TECHNICAL NOTE}

1. The main data source for the ROI analysis is the Expenditure and Food Survey (EFS). Prior to 2001/02 the analysis was based on the Family Expenditure Survey (FES) which was the predecessor of the EFS. The EFS (and previously the FES) covers all private households in the UK (that is, not people living in institutions such as prisons, retirement homes or in student accommodation). It provides information about how income and expenditure patterns differ across different types of households. For further details see Family Spending at:

www.statistics.gov.uk/familyspending

2. From 1996/97 ROI estimates are based on a sample weighted to adjust for differential rates of non-response. Prior to this date, estimates were based on an unweighted sample of responding households.

3. Company cars were included in the ROI definition of income from 1990. The effect of this change was to increase the Gini coefficient for equivalised disposable income by 0.5 percentage points (based on data for 1990). Until 2001/02 water charges were treated as a direct tax, whereas from 2002/03 they were regarded as expenditure. This change resulted in a small reduction in inequality of disposable income.

4. A household is deemed to be retired when more than 50 per cent of the household income is received by retired members of the household (an individual is deemed to be retired either if they describe themselves as 'retired', or they are over state pension age and either 'unoccupied' or 'sick or injured but not intending to seek work').

5. The Gini coefficient is a measure of income inequality taking values between 0 and 100, with higher values denoting higher levels of inequality. A value of 0 indicates complete equality in the distribution of household income (all households have the same equivalised income). A value of 100 indicates complete inequality (one household has all the income, and the others have none). For further details see: www.statistics.gov.uk/about/ methodology_by_theme/gini/default.asp 